derzhava, rehion, pidpryiemstvo, 1, 185-208.

7. Kozachenko, H. V., Pohorelov, Yu. S. (2015). Otsiniuvannia ekonomichnoi bezpeky pidpryiemstva: analiz osnovnykh pidkhodiv. Menedzhment bezpeky derzhavy, rehionu, pidpryiemstva: problemy $i$ vyklyky sohodennia. Lviv: Liha-Pres, 238-251.

8. Nusinov, V. Ya., Mishchuk, Ie. V., Izmaylov, Ya. (2019). Development of the stereometric method to the analysis of economic categories and processes and its application in security and taxation. Baltic Journal of Economic Studies, 5 (4), 160-170. doi: http://doi.org/10.30525/2256-0742/2019-5-4-160-170

9. Mishchuk, Ye. V. (2020). Otsinka stanu vydiv ekonomichnoi bezpeky, roztashovanykh na vyshchykh shchabliakh yii iierarkhii (na prykladi bezpeky tekhniko-tekhnolohichnykh interesiv ukrainskykh hirnychodobuvnykh pidpryiemstv). Internauka, 4 (36), 36-44.

10. Nusinov, V. Ya. (2016). Assessment of the severity of the financial crisis of Ukrainian companies. East European Scientific Journal, 14, 81-88.

Mishchuk Ievgeniia, PhD, Associate Professor, Department of Accounting, Taxation, Public Administration and Administration, Kryoyi Rih National University, Kryvyi Rih, Ukraine, e-mail: tdutybz.077@gmail.com,ORCID: http://orcid.org/00000003-4145-3711
Nusinov V., Ishchenko M., Polishchuk I..
UDC 658:330.131

JEL Classification: D81, E23, L69

DOI: $10.15587 / 2706-5448.2020 .220559$

\title{
DEVELOPMENT OF STRATEGIC GUIDELINES FOR MINING ENTERPRISES IN THE MANAGEMENT OF THEIR BUSINESS ACTIVITIES
}

The object of research is the process of determining the strategic guidelines for mining enterprises. The strategic positions of Metinvest B. V. (Netherlands) are analyzed using the BCG Grows-Share Matrix. It is found that this is the limiting position between the «Children» and «Dogs» quadrants. The deteriorating market conditions are indicated. It is found that getting rid of strategic business units and main strategic areas of management in the portfolio is inappropriate given the effect of «currency dumping». It is determined that its use became possible in conditions of a fall in the exchange rate of the national currency in relation to the main currency of international settlement transactions. It is determined that out of the five key strategic areas of business of Metinvest B. V., represented by the main export markets to the countries of Central and Eastern Europe and Asia, the volume of sales of the company's products only to China has a growing trend. The conclusion about the stage of the life cycle «Growth» is made. It is revealed that for all four markets of Central and Eastern Europe, the general linear trend is downward, and these strategic economic zones are located in the «Cows» square. The role of the markets of Central and Eastern Europe in the portfolio of the analyzed company as generators of cash flow («donors»), which practically do not require additional funding, is formulated. It is proposed to invest funds received from the sale of iron ore products to the markets of Central and Eastern Europe in increasing supplies to China (position «Children»), which has the largest growth prospects in the company's portfolio. It is taken into account that for China, Ukrainian mining companies are not the main suppliers. The key economic indicators of the world leaders of the mining industry are predicted until 2025. It is proposed to take into account the global dynamics in the formation of strategic management of business activities of Ukrainian enterprises. This will allow to correctly prioritize and focus on achieving competitive advantages, at least at the regional level. The result of this research is the developed strategic guidelines for mining enterprises. The use of the developed strategic guidelines will allow to introduce a targeted approach to business management of mining enterprises, taking into account the relevant environmental conditions.

Keywords: diversified company, asset utilization efficiency, competitive advantages, strategic areas of management, growth rate, target approach.

Received date: 03.08 .2020

Accepted date: 25.09 .2020

Published date: 30.09 .2020
Copyright (C) 2020, Nusinov V., Ishchenko M., Polishchuk I. This is an open access article under the CC BY license (http://creativecommons.org/licenses/by/4.0)

\section{Introduction}

Scientific works on economics and business management focus on static phenomena [1, 2], containing proposals for achieving success in entrepreneurship based on the growth and challenges of the 21 st century [3, 4]. With the development of the management paradigm, there came an understanding of the importance of a scientifi- cally grounded approach to restructuring the enterprise management system [5, 6], as well as accounting for risk prediction [7]. However, such works do not take into account the industry specifics of enterprises. Certain strategic aspects of enterprise management are highlighted in [8]. In works $[9,10]$, methods are proposed that can be used for mining enterprises and focus on investment as one of 
the strategic priorities of their development. Therefore, in the scientific literature, the target approach to business management of mining enterprises is fragmentary, taking into account the relevant environmental conditions.

So, the object of research is the process of determining the strategic guidelines of mining enterprises. The aim of research is to develop strategic guidelines for mining enterprises in the management of their business.

The feasibility of developing such guidelines is increasing in the current period of overlapping economic and sectoral crises and the consequences of the COVID-19 pandemic. Business management of mining companies should focus on strategic areas of management. Taking into account their characteristics, as well as the dynamics that are predicted for the next five years, should provide key directions for these companies in their search for opportunities for survival and further development. The above indicates the relevance and timeliness of research on the strategic guidelines of mining enterprises in the management of their entrepreneurial activities.

\section{Methods of research}

The dialectical method, the method of analysis and synthesis were used in the study and generalization of scientific concepts for defining strategic zones of management, as well as in their identification for mining companies. Economic forecasting methods were used to determine the strategic benchmarks of mining companies.

\section{Research results and discussion}

According to the research results, the authors found that within the framework of the BCG Grows-Share matrix, the business cycle is declining in 2019. The company can be in the «Cows» or «Dogs» square, depending on its market share. Therefore, in order to select a strategy, it is important to determine the exact positions of the company. When building a portfolio matrix for Metinvest B. V. (Netherlands) is proposed not to consider the metallurgical direction of its business. This is due to the influence of force majeure factors that are unpredictable. In addition, most of the business units in this area of the company have moved out of management and control.

When calculating the parameter of the «Relative market share» matrix, the ratio of total (consolidated) sales of products by Metinvest B. V. was used to the domestic and foreign markets with the sales volumes of iron ore raw materials of the world's largest manufacturer Vale S. A. (Brazil). Vale S. A. is one of the big three mining multinational corporations along with Rio Tinto Limited (Australia/UK), BHP Group Limited (Australia/UK). These corporations, on the basis of an oligopoly conspiracy, dictate the conditions and prices on the world iron ore market [11]. To determine the rate of market growth, the total volume of demand for the markets was used to which Metinvest B. V. actually sold since 2006. Similar calculations were carried out for its main competitor, Vale S. A. The calculated values of the parameters of the market growth rate and the relative market share using the BCG Grows-Share matrix for Metinvest B. V. compared to Vale S. A. are given below in Table 1 [11].
Table 1

The parameters of the market growth rate and the relative market share calculated using the BCG Grows-Share matrix for the iron ore business of Metinvest B. V. (Retrospection)

\begin{tabular}{|c|c|c|c|c|}
\hline \multicolumn{2}{|c|}{$\begin{array}{l}\text { Sales volume of iron оге } \\
\text { raw materials, million tons }\end{array}$} & \multirow{2}{*}{$\begin{array}{c}\text { Metinvest B. V. } \\
\text { relative market } \\
\text { share, \% }\end{array}$} & \multicolumn{2}{|c|}{$\begin{array}{l}\text { Average annual market } \\
\text { growth rate, } \%\end{array}$} \\
\hline $\begin{array}{l}\text { Metinvest B. V. } \\
\text { enterprises }\end{array}$ & $\begin{array}{l}\text { Vale S. A. } \\
\text { company }\end{array}$ & & $\begin{array}{c}\text { Metin- } \\
\text { vest B. V. } \\
\text { sales markets }\end{array}$ & $\begin{array}{c}\text { Vale S. A. } \\
\text { sales } \\
\text { markets }\end{array}$ \\
\hline 25.65 & 287 & 8.94 & 14.42 & 8.93 \\
\hline
\end{tabular}

Note: based on data from [11]

Based on the obtained parameter values, the BCG GrowsShare matrix was built for Metinvest B. V. in relation to the market leader in iron ore raw materials - Vale S. A. Let's note that due to the different geography of supplies of competing companies, different values of the market growth rate were obtained: Metinvest B. V. - $14.42 \%$, Vale S. A. $8.93 \%$. Thus, the strategic zones for the sale of iron ore raw materials by Metinvest B. V. are the markets of Europe and Asia, and Vale S. A. - Europe, Asia and South America. This difference is mainly due to the decline in imports in South America, where Vale S. A. supplies products. According to the obtained strategic positions of Metinvest B. V. according to the BCG Grows-Share matrix, in fact it is located in the «Children» square, but at the same time the company's position is as close as possible to the «Dogs» quadrant (the limiting position of the company is fixed between the «Children» and «Dogs» quadrants).

Let's note that the peculiarity of the construction of this matrix is the use of market volumes in physical terms. However, the most important characteristic of demand is its volume in monetary units. In particular, in the iron ore market, these volumes are decreasing due to a decrease in the price environment, which is not taken into account by the matrix. In connection with the above, it is possible to give an unambiguous interpretation of the positions of the iron ore business of the company. In this case, one should take into account the limiting position according to the matrix, as well as other factors. These factors are that since 2013, sales volumes have decreased in monetary terms due to a decrease in the price environment. In addition, the growth rates of steel production and demand for iron ore raw materials in China fell. At the same time, the fall in the price environment for iron ore raw materials by almost 3 times since 2011 was compensated by the effect of «currency dumping» with an increase in the USD against the UAH by about 3.4 times. This circumstance, due to the large share of exports in the structure of supplies by the company's enterprises, neutralizes the negative impact of the decline in prices for iron ore raw materials on the world market. Based on this, let's assume that the company as a whole, like its enterprises (strategic business units), is in crisis. Given the company's ambiguous positions on the BCG Grows-Share matrix, it is advisable to determine how each of the strategic areas of management affected the company's financial condition.

Taking into account the current situation, represented by the influence of force majeure factors, it is proposed to manage entrepreneurial activity:

1. Definition of the company's iron ore business as key.

2. Change of the main direction of iron ore supplies from the domestic to the foreign market. This event is proposed 
for the reason that most of the metallurgical business in Ukraine is concentrated on the territory, in the current conditions it is uncontrollable. At the same time, under the control of Metinvest B. V. The following factories are located: PJSC «llyich Iron and Steel Works», Mariupol, Ukraine and Open Joint Stock Company «Metallurgical Plant» Azovstal». Their business activities in the medium term are associated with certain risks. The emphasis on foreign economic activity is effective due to the growth in the exchange rate of the main settlement currency in the international market for the supply of iron ore, the USD to UAH, which allows using the effect of «currency dumping». The latter is the most important strategy tool for survival and growth opportunities that can be used to achieve business profitability based on changes in the exchange rate of the dollar against the national currency. The implementation of the above measures allows Metinvest B. V. compete and increase shares in foreign markets, using the advantage of «currency dumping» and economies of scale in the company's supplies in key areas. Their determination is the task of the next step of the analysis.

It should be emphasized that the domestic market of Ukraine for building a portfolio matrix is excluded. When considering the strategic areas of economic management of the enterprises of Metinvest B. V. it is important to take into account that many of them supply the same markets, but do not compete with each other. In fact, Metinvest B. V. directly competes with other market participants. The study of consolidated supplies is also justified in terms of the synergy of the vertically integrated structure. This synergy manifests itself through the economies of scale of supply in the form of reduced fixed costs, as well as an increase in the overall market power of the company in each market (in the negotiation process). The compound annual growth rate (CAGR) for the ten-year period for the markets of the company in Central and Eastern Europe was $-3.15 \%$, and the overall market growth rate for them in the same period was $-20.64 \%$. In this regard, it is possible to state a drop in demand in all the main sales markets of the company in the countries of Central and Eastern Europe for 10 years, an average of $-2.06 \%$ per year: for the Czech Republic, the market growth rate was $-2.41 \%$, Hungary $5.24 \%$, Slovakia - $0.03 \%$, Poland $-2.41 \%$. At the same time, Ukrainian companies [12] are the main exporters to the European sales markets represented by the countries of Central and Eastern Europe with particles relative to their main competitors:

- on the Czech market: Ukraine - $68 \%$, Russia - $19 \%$, Brazil - $12 \%$;

- on the Slovak market: Ukraine - $51 \%$, Russia - $46 \%$;

- on the Hungarian market: Ukraine - $25 \%$, Russia $-26 \%$, Sweden - $26 \%$, Brazil - $23 \%$.

According to data from [11], Ukraine ranks 5 th and is among the TOP-5 largest exporters of iron ore to China: Australia - $50.32 \%$, Brazil - $9.54 \%$, South Africa $4.91 \%$, India - $2.08 \%$, Ukraine - $2.07 \%$. At the same time, Metinvest B. V. is one of the largest companies in the supply of products, competing with the Private Joint Stock Company «Poltava Mining and Processing Plant» for deliveries to Slovakia, as well as with the Public Joint Stock Company «Kryvyi Rih Iron Ore Integrated Plant» combine for deliveries to the Czech Republic, Hungary and Poland. In the direction of export to China, the main competitor of the company is the main exporter to this market - Vale S. A. To determine the main strategic areas of management in the company's portfolio, their total supply volumes for each market were calculated.

It was revealed that the general linear trend of sales volumes of iron ore raw materials in the main strategic areas of management of Metinvest B. V., in particular Central and Eastern Europe, is downward. At the same time, for the strategic economic zones of China, it has the largest share in world imports, as well as in the supplies of Metinvest B. V., the trend is growing. However, despite the downturn in Eastern Europe, the company is in the Cows square in all of its major markets. This allows us to assert that the life cycle for the main markets of Central and Eastern Europe, in particular the Czech Republic, Slovakia, Hungary, is in a state of transition from the «Maturity» (stability) stage to the «Recession» stage. This is due to the transition at the end of the $20^{\text {th }}$ century to the «era of Asia» and the shift in the focus of the geography of world steel production from Europe to Asia. Let's note that due to the release of supply volumes from the domestic market, leaving the markets of Central and Eastern Europe is inappropriate.

Taking these prerequisites into account, the following strategy for managing the company's entrepreneurial activity is proposed in the context of strategic areas of management. It is necessary to focus on the main sales markets of Central and Eastern Europe (Czech Republic, Slovakia, Hungary, Poland) as a source of income. As these markets have the ability to generate cash flow, ensure profitability and competitiveness through the effect of «currency dumping». At the same time, the prospect of leaving these sales markets from the «Cows» quadrant to «Stars» with the transition to the «Growth» stage in the next business cycle from 2022 is not excluded. The Big Three, in particular Vale SA China's strategic economic zone is key for the company - it accounts for $66.54 \%$ of the company's total iron ore supplies. It is located in the «Children» square and has the prospect of growth, since the cash flows generated from sales to Central and Eastern Europe can be used to finance it, in particular, to provide competitive advantages in product price and quality. In the future, as a result of the transition from the «Maturity» stage to the «Recession» stage of the life cycle in the markets of Central and Eastern Europe, it is also necessary to consider the possibility of a gradual redistribution of the released sales volumes from these markets to the Chinese market. In addition, it is important to consider investing in measures aimed at reducing the cost of freight. At the same time, one should take into account the large transport leverage (less profitable than in the key competitors of the Big Three) when delivering to the key sales market of China and the increased requirements for the quality of iron ore. The reason for the high freight costs is also the fact that the depth of the Suez Canal (which determines the shortest route to the ports of China) limits the maximum type of Capsize vessels (100 thousand tons). At the same time, the port infrastructure in Ukraine is poorly developed and does not always allow efficient loading of vessels of this type. All these aspects have led to a decrease in the competitiveness of Metinvest B. V. products. a key strategic economic zone in China. Therefore, it is advisable to direct certain investments to finance measures to reduce the cost of supplies in this direction. 
Thus, one of the strategically priority areas of financing activities through proceeds from the sale of products to the countries of Central and Eastern Europe, as well as China, is the development of port infrastructure and the shipbuilding industry in Ukraine.

So, it is obvious that in order to successfully manage the entrepreneurial activities of domestic mining companies, it is necessary to take into account new trends under the influence of the overlapping economic and industrial crisis, as well as the COVID-19 pandemic. According to forecasts of the International Monetary Fund, the global economy will contract by $3 \%$. However, it is impossible to stop the development of scientific and technological progress, which so far correlates with Industry 4.0. New technologies are penetrating deeper into both the financial and operational activities of mining companies. The latter will lead to an improvement in the technical and technological base, information armament and, finally, will contribute to an increase in labor productivity. It is known that as a result of scientific and technological progress, the financial results of a company should grow by $5 \%$ [13]. However, given the consequences of the pandemic, based on the factor analysis carried out, there is reason to believe that the impact of scientific and technological progress in 2024 will provide an opportunity for growth by only $2 \%$. Most of all, this concerns indicators of profitability, security and efficiency of the use of non-current assets (including the share of IT capital), inventory turnover, labor productivity. Only starting from 2024 the impact of scientific and technological progress will cease to be leveled by the consequences of the COVID-19 pandemic quarantine. Then the annual $5 \%$ growth of these indicators will be restored due to the influence of scientific and technological progress.

It should be noted that at the end of 2019, the TOP-40 rating of the largest mining companies by market capitalization changed, but the top three leaders continued to be led by BHP Group Limited (Australia/UK), Rio Tinto Limited (Australia/UK) and Vale S. A. (Brazil) [14]. These diversified companies are the most influential, and therefore continue to set standards and other targets in health, industrial safety and key economic indicators. In this regard, the authors analyzed the data of their activities, as well as of other companies from the TOP-40 world leaders in the industry in order to predict the dynamics of key economic indicators in 2025. The main economic indicators of the companies were analyzed:
- Anglo American plc, UK/South Africa (diversified company);

- Fortescue Metals Group Limited, Australia (iron ore);

- Grupo Mexico S.A.B. de C.V., Mexico (diversified company);

- Zijin Mining Group Company Limited, China (diversified company);

- Saudi Arabian Mining Company, Saudi Arabia (diversified company), etc.

The aggregate values of some of the analyzed indicators for 2011-2019 are given in Table 2 [14].

Such changes should be noted. During 2018-2019 there was a $4 \%$ increase in revenues (692 billion USD), with a decline in pre-tax profit by $11 \%$ (89 billion USD) and an increase in dividend payments by $25 \%$ (55 billion USD) [14]. Without taking into account the entry of the industry into the crisis and the COVID-19 pandemic, based on the ten-year trend, the growth in profit before tax would look like the one shown in Fig. 1.

Table 2

Dynamics of individual economic indicators of the TOP-40 of the world's largest mining companies by market capitalization, billion USD

\begin{tabular}{|c|c|c|c|c|c|c|c|c|c|}
\hline Index & 2011 & 2012 & 2013 & 2014 & 2015 & 2016 & 2017 & 2018 & 2019 \\
\hline Proceeds & 716 & 731 & 719 & 690 & 539 & 496 & 600 & 683 & 692 \\
\hline Operating expenses & 487 & 553 & 554 & 531 & 448 & 390 & 454 & 518 & 515 \\
\hline Operating profit & 229 & 178 & 165 & 159 & 91 & 106 & 146 & 165 & 168 \\
\hline $\begin{array}{c}\text { Depreciation of property, plant and } \\
\text { equipment and intangible assets }\end{array}$ & 26 & 34 & 42 & 48 & 42 & 44 & 41 & 47 & 50 \\
\hline Financial expenses & 6 & 6 & 16 & 15 & 19 & 9 & 11 & 13 & 14 \\
\hline Profit before tax & 181 & 93 & 50 & 69 & -23 & 34 & 90 & 93 & 89 \\
\hline Operating profitability, \% & 32 & 24 & 23 & 23 & 17 & 21 & 24 & 24 & 24 \\
\hline Dividend payments & 33 & 38 & 41 & 40 & 28 & 16 & 36 & 43 & 55 \\
\hline Cash & 113 & 104 & 168 & 83 & 82 & 86 & 102 & 101 & 88 \\
\hline Fixed assets & 601 & 701 & 712 & 745 & 579 & 616 & 663 & 610 & 649 \\
\hline Total assets & 1139 & 1245 & 1256 & 1231 & 1047 & 1063 & 1129 & 1080 & 1139 \\
\hline Total liabilities & 482 & 563 & 624 & 630 & 569 & 563 & 573 & 540 & 576 \\
\hline
\end{tabular}

Note: based on the data of the analytical report [14]

Profit before tax, billion USD

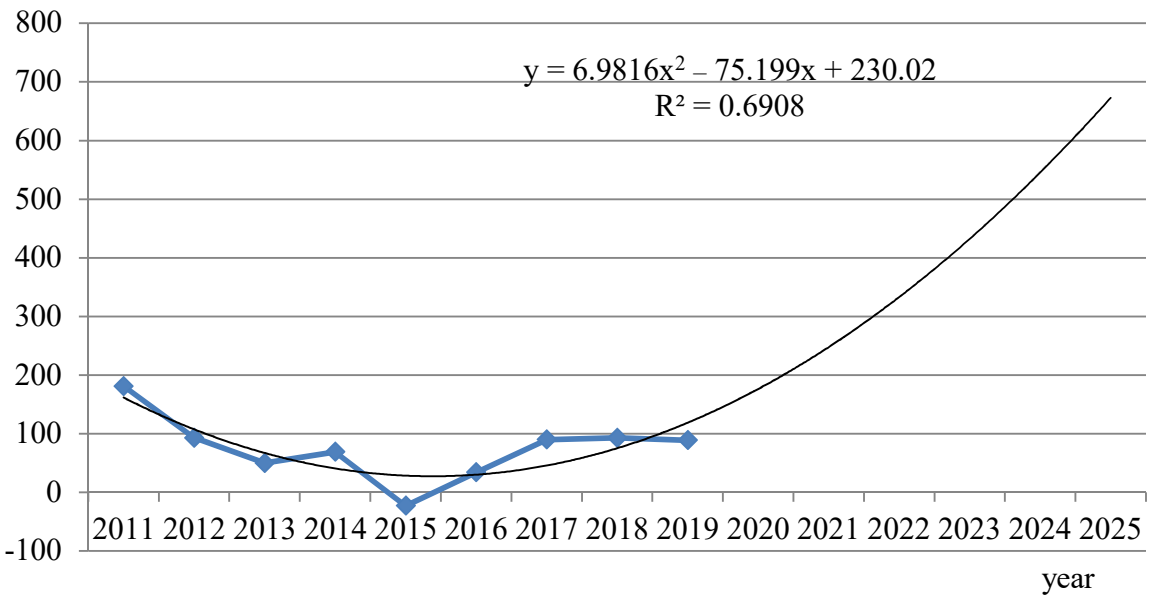

Fig. 1. Dynamics of profit before tax of the TOP-40 of the world's largest mining companies by market capitalization in 2011-2019 (constructed by the authors based on data from [14])

However, despite the fact that 2020 is not over yet, analysts $[14,15]$ predict a $6 \%$ decrease in operating profit for the first half of the year. This value does not correspond to the given dynamics. 
Further calculations did not take into account the data of highly specialized companies such as Kinross Gold Corporation (Canada), Polymetal International plc (Russia), ALROSA (Russia) and other companies whose activities are aimed at the production of gold, diamonds, and the like.

During the entire period of the outbreak of the COVID-19 pandemic, prices for iron ore remained at the level of 80 USD per ton [16]. According to forecasts, the average price in 2020 will remain at the level of 90 USD per ton, but in 2021 it is highly likely that it will increase by more than 10 USD per ton compared to 2020. World leaders in the industry reached their highest production level when China began to rebuild its economy in Q1 2020. Revenue growth in 2019 did not lead to an increase in profit before tax, which in general decreased by $11 \%$ per year (Table 2). Significant reasons for the negative dynamics were the growth of obligations to eliminate the consequences of the collapse of the tailing dam in Brazil, as well as the depreciation of assets (including the Assets of Rio Tinto Limited in the amount of 3.5 billion USD). Excluding the value of these liabilities, the reduction in profit before tax would have been $3 \%$. PwC analysts predict also in 2020 a drop in revenue by $6 \%$ [14]. To predict the dynamics, it should be taken into account that, according to expectations, China plans to increase funding for its own infrastructure facilities. At the same time, according to estimates of the International Monetary Fund, India's GDP is expected to grow by $1.9 \%$ in 2020 , and by $7.4 \%$ in 2021 said to promote the growth of consumption in this country. Therefore, based on the forecasts of $\mathrm{PwC}$ analysts, we note that until 2022, the priority of mining companies will be product, and not capital investments to expand their activities. Because of this, and also taking into account the requirements of antitrust legislation, the maximum market share of the industry leader (Vale S. A.) will be $25 \%$ in 2024 with an average growth rate of 1.06.

Despite the noted, operating profit in 2019 has not changed significantly. At the same time, the introduction of a new international financial reporting standard for leases gave rise to $1 \%$ growth. This measure contributed to the reclassification of a significant part of the costs and their attribution to depreciation accounts [14]. Taking into account the calculations, the projected average growth rate of the return on operating profit costs is 1.1 for 2019-2024. The highest value will be 0.9 in 2024 at BHP Group Limited a higher rate can be achieved in terms of return on fixed assets (1.6). The highest level of profit for every dollar invested in fixed assets in 2024 - 1.6, while the value in the IV quarter of this year was 0.4 .

During the pandemic, there were imperfections in the models of globalization of supply chains, the principles of economical consumption and the «just in time» method. The most affected are those companies that employed temporary workers, had small inventories and were not diversified [16-18]. Anglo American plc and BHP began to actively address these deficiencies, which introduced programs to support business relations with local suppliers. This will allow during 2019-2024 obtain the growth rate of the turnover of materials and raw materials in the amount of 1.3. At the same time, the BHP will have the best value in the II quarter of 2024 - 11 and 44 at the end of this year.

Despite the active development of Industry 4.0 , the management policy of global mining companies in the field of digitalization of operating activities can be called moderate. Inexplicably critical is the percentage of CEOs who are concerned about cybersecurity: $12 \%$ in 2020 versus $21 \%$ in 2108, while worldwide their share is $33 \%$ [14]. It was revealed that by 2025 the growth rate of the share of IT capital in the total value of fixed assets and intangible assets of companies will be 1.1. At the same time, the highest value of the share of IT capital at the end of the period will be in BHP Group Limited at $1 \%$.

There is a substitute to believe that with the same dynamics of production automation, the changes that affected the transition to remote work, the reduction in the share of office buildings, the use of local labor resources will remain in the future. Moreover, in the future - more distant than five years. Prior to 2019, BHP Group Limited and other leaders were reaping more than 12 billion USD in productivity savings [14]. Rio Tinto Limited practiced alternative patterns of personnel use for the pandemic, so it was better prepared than others for new challenges. In this connection, the company already in 2020 felt the effects of reducing the time for transporting workers to jobs while maintaining production volumes. This company has formed three centers of excellence, which allowed it to receive 1.5 billion USD of additional cash flows through improved productivity, and Anglo American plc pledged to increase operating income by $3-4$ billion USD by 2022 . Labor productivity is projected to grow at the fastest pace in Rio Tinto Limited (1.7 for 2019-2024 biennium) and will reach 73 thousand US dollars per person in the III quarter of 2024 with an average annual value of 293 thousand USD per person.

Through operating activities and with the use of attracted capital in 2020, real investment projects continued to be financed. At the same time, compared to 2019, their value decreased and amounted to a total of about 50 billion USD. In 2020, capital investments are projected to decrease by at least $20 \%$ [14]. The forecasts made allow us to assert a slowdown in the rate of capital investment compared with the previous period until 2022. And their gradual increase until 2025 . So, during 2019-2024 the average rate of fixed assets renewal is projected at the level of 1.35 (with the best sense of the share of acquired fixed assets in the first quarter of 2024 in Vale SA 0.14 and the average annual rate of 0.56). The successful implementation of the development strategy of this Brazilian company provides for the growth rate of indicators of the usefulness of fixed assets and their return in 2024 at the levels of 1.17 and 1.38. In the same year, their values may be 0.94 and 2.8 , respectively (at 0.7 for the quarterly value of the volume of production will fall on 1 USD of fixed assets).

Let's consider it appropriate to point out the growth of interest-bearing loans and the growth of the debt-toequity ratio in mining companies, which in 2019 amounted to $31 \%$ versus $29 \%$ in 2018 The growth of short- 
term liabilities is associated with the need to repay part of long-term debt, the maturity of which approached exactly in 2019 gradually decreased, approaching the values in 2013 for the period 2015-2019. The share of short-term loans in the total liabilities of world leaders in the mining industry fluctuated slightly, ranging from $16 \%$ (2015) to $18 \%$ (2019). Net working capital, which in 2015 amounted to 38 billion USD, most of all grew in 2017 - 48 billion USD, and in 2019 decreased by $34 \%$ [14]. A small growth rate of the current liquidity ratio was found during 2015-2018 (from 1.41 to 1.63) and a subsequent drop in 2019 up to 1.41 (actually up to the level of 2015). Determination of key points of change in trends in the values of liquidity indicators made it possible to predict the growth rate of the corresponding ratios (1.05 for current liquidity for 2019-2025).

It is known that about $85 \%$ of the energy consumed by the mine is fossil fuels. The demand for energy in mining companies is increasing significantly due to the decrease in the iron ore grade in the existing deposits. In this regard, the production process is becoming more energy intensive and water-containing. At the same time, in 2030, the deadline set by the Intergovernmental Panel on Climate Change to reduce global emissions by half will expire. The limiting value of specific emissions of pollutants into the air for mining and processing plants should be $0.3 \mathrm{~kg} / \mathrm{t}$, for mines $-0.041 \mathrm{~kg} / \mathrm{t}$. This requires not so much strategic, but also operational measures on the part of companies. In addition, there is a growing influence on mining companies from global and other international organizations. Specifically, the World Bank has developed a climate-preserving minerals initiative. Investors led by the Church of England Pension Board and the Swedish Fund Ethics Council have created a number of initiatives. These include initiatives to improve the safety of mining operations and tailings and establish an international standard for tailings. All this, as well as the factors associated with reducing production costs, encourage companies to implement measures to reduce the material and energy consumption of products. It is predicted that the highest rate of reduction in material consumption will be in 2019-2024 (0.55), while a better ratio of material costs to production volumes will reach 0.05 in 2024 at Vale S. A. The same company can become a leader in reducing electricity consumption. The rate of decrease in energy intensity is forecasted at the level of 0.6 , or, better, the value of 0.03 .

Thus, the available forecasts characterize the overall stable financial position of the world leaders in the mining industry. At the same time, the Ukrainian mining enterprises have much more difficulties, not only financial, but also of a geopolitical nature.

\section{Conclusions}

Thus, the strategic positions of Metinvest B. V. are defined using the BCG Grows-Share Matrix. It was found that this is the limiting position between the «Children» and «Dogs» quadrants. The deteriorating market conditions are indicated. It was found that getting rid of strategic business units and main strategic areas of management in the portfolio is inappropriate given the effect of «currency dumping». It was determined that its use became possible in the context of a fall in the exchange rate of the national currency in relation to the main currency of international settlement transactions. It was determined that out of the five key strategic areas of business of Metinvest B. V., represented by the main export markets to the countries of Central and Eastern Europe and Asia, the sales volumes of the company's products only to China have a growing trend. The conclusion about the stage of the life cycle «Growth» is made. It was revealed that for all four markets of Central and Eastern Europe, the general linear trend is downward, and these strategic economic zones are located in the «Cows» square. The role of the markets of Central and Eastern Europe in the portfolio of the analyzed company as generators of cash flow («donors»), which practically do not require additional funding, was formulated. It was proposed to invest funds received from the sale of iron ore products to the markets of Central and Eastern Europe in increasing supplies to China (position «Children»), which has the largest growth prospects in the company's portfolio. It is taken into account that for China, Ukrainian mining companies are not the main suppliers. The key economic indicators of the world leaders of the mining industry are predicted until 2025. It is proposed to take into account the global dynamics in the formation of strategic management of business activities of Ukrainian enterprises. This will allow to correctly prioritize and focus on achieving competitive advantages, at least at the regional level. As a result of the study, strategic guidelines for mining enterprises have been developed. The use of the developed strategic guidelines will allow to introduce a targeted approach to the management of entrepreneurial activities of mining enterprises, taking into account the relevant environmental conditions.

The direction of further research is the development of a comprehensive mechanism for the implementation of certain strategic guidelines in the model of strategic enterprise management.

\section{References}

1. Mcconnell, C. R., Brue, S. L., Flynn, S. M. (2009). Economics: Principles, problems, and policies. Boston: McGraw-Hill/ Irwin, 917.

2. Laplume, A., Yeganegi, S. (2009). Entrepreneurship Theories Spring. Available at: https://www.entrepreneurshiptheories.com/ about/

3. Davidsson, P.; Katz, J., Shepherd, S. (Eds.) (2003). The Domain of Entrepreneurship Research: Some suggestions. Advances in Entrepreneurship, Firm Emergence and Growth, 6, 315-372. doi: http://doi.org/10.1016/s1074-7540(03)06010-0

4. Druker, P. (2012). Menedzhment. Vyzovy XXI veka. Mann, Ivanoz $i$ Ferber. Available at: https://www.libfox.ru/405163-11-piterdruker-menedzhment-vyzovyxxi-veka.html\#book

5. Drljača, M. (2015). Restructuring of the management system and the role of top management. Quality for Future of the World, International Academy for Quality. Budapest.

6. Tiller, S. R. (2012). Organizational Structure and Management Systems. Leadership and Management in Engineering, 12 (1), 20-23. doi: http://doi.org/10.1061/(asce)lm.1943-5630.0000160

7. Susca, P. T. (2018). Using processes to prevent and predict risk. Professional Safety, 63 (8), 18-21.

8. Mishchuk, I. (2020). Evaluation of the performance of implementation of strategic measures of ensuring economic security of enterprises. Technology Audit and Production Reserves, 2 (4 (52)), 4-10. doi: http://doi.org/10.15587/2312-8372.2020.199962 
9. Kashubina, Yu. B., Mishchuk, Ye. V. (2015). Definitsii ekonomichnoi katehorii «investytsiina bezpeka». Investytsii: praktyka ta dosvid, 2, 12-18.

10. Mishchuk, I. V. (2017). Determination of Components of Investment Attractiveness of Enterprises and Industries as Factors of their Securit. Problemy ekonomiky, 1, 94-104.

11. Babets, Ye. K., Melnykova, I. Ye., Hrebeniuk, S. Ya., Lobov, S. P. (2015). Doslidzhennia tekhniko-ekonomichnykh pokaznykiv hirnychodobuvnykh pidpryiemsto Ukrainy ta efektyonosti yikh roboty $v$ umovakh zminnoi koniunktury svitovoho rynku zalizorudnoi syrovyny. Kryvyi Rih: Vydavnychyi dim, 390.

12. Ukrpromvneshekspertiza (2016). Sovremennoe sostoianie i ozhidaemoe razvitie rynka ZHRS v sleduiuschem godu. Ezhegodnii prognoz. Available at: http://www.expert.kiev.ua/

13. Rozenplenter, A. E., Shirokoradova, B. R. (1984). Osnovy up ravleniia sozdaniem novoi tekhniki. Kyiv: Vischa shkola, 160.

14. Analitychnyi zvit PwC (2020). Hirnochydobuvna promyslovist: iz zapasom syl ta resursiv, 32 .

15. Pidsumky roboty HMK Ukrainy u 2019 r. Available at: http:// www.ukrmetprom.org/pidsumki-roboti-gmk-ukraini-u-2019-r/

16. Metallurgiia: globalnye trendy 2020. Available at: https://gmk center/wp-content/uploads/2020/03/Metallurgiya-Globalnyetrendy-2020.pd

17. Pidsumky roboty HMK Ukrainy za I pivrichchia 2020 r. (2020).
Available at: http://www.ukrmetprom.org/pidsumki-roboti-gmkukraini-za-i-pivri

18. Ukraina v svitovomu metalurhiinomu vyrobnytstvi za 6 misiatsiz $2020 r$. Available at: http://www.ukrmetprom.org/ukraina-vsvitovomu-metalurgiynomu-v-13/

Nusinov Volodymyr, Doctor of Economic Sciences, Professor Academician of Academy of Economic Sciences of Ukraine, Department of Accounting, Taxation, Public Administration and Administration,Kryoyi Rih National University, Kryvyi Rih, Ukraine, e-mail:vladimirya15@gmail.com,ORCID: http://orcid.org/00000003-2367-0317

Ishchenko Mykola, Doctor of Economic Sciences, Professor, Vice President of the Academy of Mining Sciences of Ukraine, Department of Accounting, Taxation, Public Administration and Administration, Kryvyi Rih National University, Kryvyi Rih, Ukraine, e-mail: tdutybz.077@gmail.com,ORCID: http://orcid.org/00000003-0726-4175

Polishchuk Irina, PhD, Associate Professor, Department of Economics, Organization and Management of Enterprises, Kryvyi Rih National University, Kryvyi Rih, Ukraine, e-mail: irinapolisuk306@gmail.com, ORCID: http://orcid.org/0000-0003-0151-8656 